\title{
New species and records of short-palped crane-flies (Diptera: Limoniidae) from Krasnodar Territory, Russia
}

\author{
Новые виды и находки комаров-цимониид (Diptera: Limoniidae) \\ из Краснодарского края, Россия
}

\author{
D.I. Gavryushin \\ А.И. Гаврюшин \\ Zoological Museum, Moscow Lomonosov State University, Bol'shaya Nikitskaya 6, Moscow, 125009, Russia. E-mail: \\ dmitry_gavryushin@yahoo.com \\ Зоологический музей, Московский государственный университет им. М.В. Ломоносова, Большая Никитская ул., 6, Москва \\ 125009 Россия.
}

KEY WORDS: Diptera, Limoniidae, Limnophilinae, Chioneinae, Austrolimnophila, Scleroprocta, Russia, Krasnodar Territory, Caucasus, taxonomy, description, new species, new records.

КЛЮЧЕВЫЕ СЛОВА: Diptera, Limoniidae, Limnophilinae, Chioneinae, Austrolimnophila, Scleroprocta, Россия, Краснодарский край, Кавказ, таксономия, описание, новый вид, новые находки.

ABSTRACT. Two new species of short-palped crane-flies (Diptera, Limoniidae) are described from Russia (Krasnodar Territory, the Caucasus region), Austrolimnophila (Austrolimnophila) vikhrevi sp.n. and Scleroprocta staryi sp.n. Descriptions of males and illustrations of male genitalia are provided. Five species are recorded as new to the fauna of Russia, Ormosia (Ormosia) bicornis (de Meijere, 1920) (new for mainland Russia), Ormosia (Ormosia) longispina Savchenko, 1983, Eloeophila minor Stary, 2009, Prionolabis subcognata Savchenko, 1971, and Elliptera omissa Schiner, 1863.

РЕЗЮМЕ. Описаны два новых вида комаровлимониид (Diptera, Limoniidae) из России (Краснодарский край, Кавказ): Austrolimnophila (Austrolimnophila) vikhrevi sp.n. и Scleroprocta staryi sp.n. Даны описания самцов и иллюстрации гениталий. Пять видов впервые указываются для фауны России: Ormosia (Ormosia) bicornis (de Meijere, 1920) (новый вид для материковой части России), Ormosia (Ormosia) longispina Savchenko, 1983, Eloeophila minor Stary, 2009, Prionolabis subcognata Savchenko, 1971, и Elliptera omissa Schiner, 1863.

\section{Introduction}

The rich and diverse fauna of short-palped craneflies (Limoniidae, Pediciidae) of the Caucasus is relatively well-studied if compared with many other regions of Russia, and the most important contribution to its knowledge was done through the efforts of Evgeniy N. Savchenko (1909-1994). Still, new species have been discovered and new regional as well as country records have been added recently [Lantsov, 2009; Gavryushin,
2011]. During examination of the material collected by the author and his colleagues two species new to science belonging to the genera Austrolimnophila (s.str.) Alexander, 1920 (subfamily Limnophilinae) and Scleroprocta Edwards, 1938 (subfamily Chioneinae) were revealed.

The nominative subgenus of the genus Austrolimnophila Alexander, 1920 so far has been represented by six species in the Western Palaearctic [Oosterbroek, 2015]. Great similarity of these species led to some confusion, misidentifications, and poor understanding of their distribution. Savchenko in his impressive review of the fauna of the former Soviet Union pointed out that the common $A$. (A.) ochracea (Meigen, 1804) is apparently missing in Southern Europe and other areas, including Transcaucasia, being replaced there by a number of closely related species [Savchenko, 1989: 67]. The works by Jaroslav Starý proved this hypothesis, earlier he described two new Mediterranean species [Starý, 1977] and two more new species with the same distribution were added quite recently [Starý, 2014].

The Holarctic genus Scleroprocta Edwards, 1938 includes 8 species in the Western Palaearctic [Oosterbroek, 2015] and was initially erected as a subgenus of Ormosia Rondani, 1856 to incorporate species very different from their relatives by a number of distinct features, especially in non-inverted male terminalia, a remarkable sclerotised structure between the base of gonocoxites ventrally (ventral plate), and parameres fused together thus forming a separate structure, the parameral plate [Starý, 2008].

\section{Material and methods}

The morphological terms used here mainly follow McAlpine [1981], venation is described mostly after 

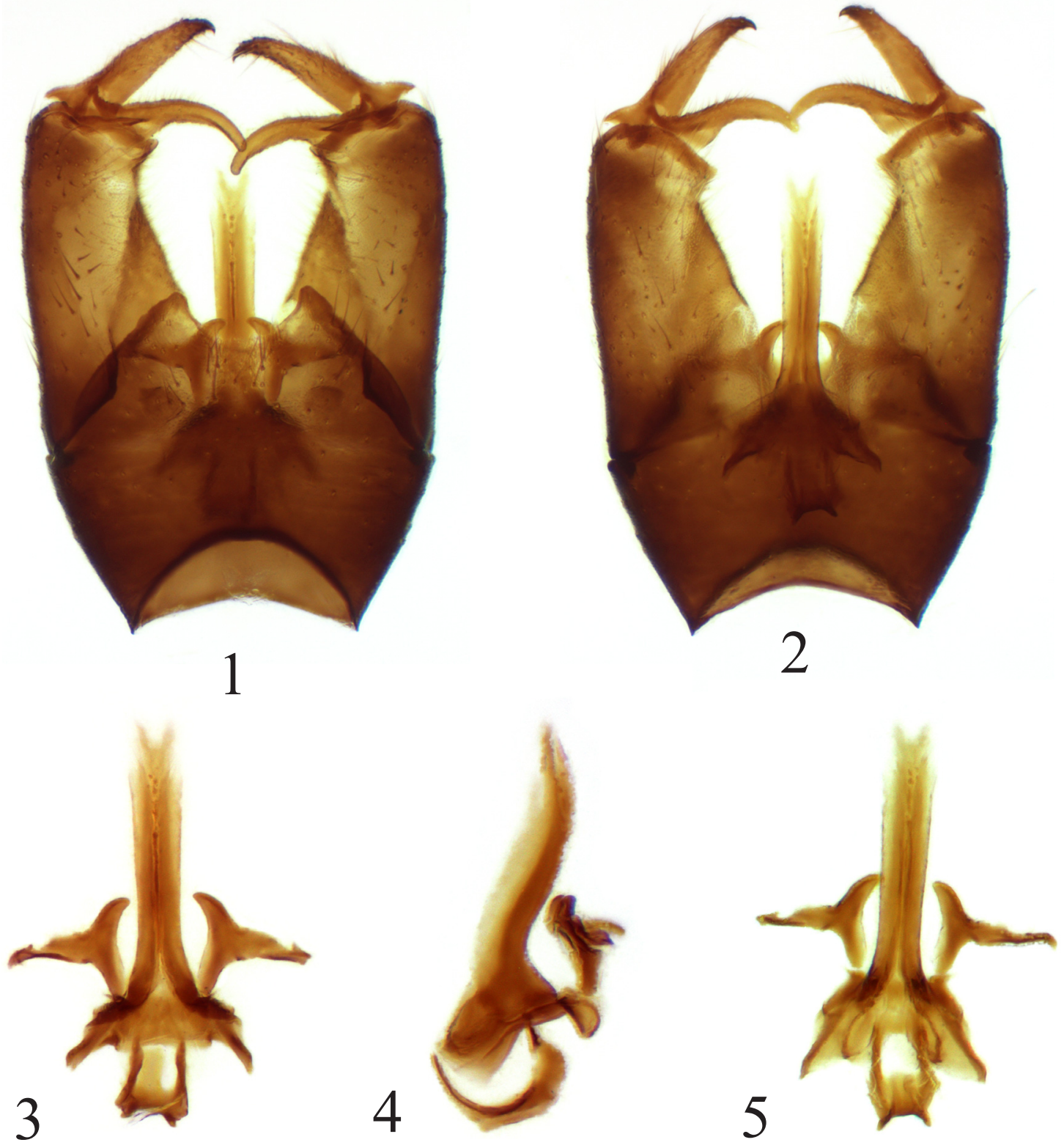

Figs 1-5. Austrolimnophila (Austrolimnophila) vikhrevi sp.n., holotype $0^{7}: 1-$ male hypopygium, dorsal view; $2-$ same, ventral view; 3 - aedeagal complex, dorsal view; 4 - same, lateral view; 5 - same, ventral view. Not on same scale.

Рис. 1-5. Austrolimnophila (Austrolimnophila) vikhrevi sp.n., голотип О: 1 - гипопигий самца, вид сверху; 2 - то же, вид снизу; 3 - эдеагус, вид сверху; 4 - то же, вид сбоку; 5 - то же, вид снизу. Масштаб разный.

Alexander and Byers [1981]. Male genitalia were boiled in $10 \%$ solution of potassium hydroxide $(\mathrm{KOH})$ for 60 to $90 \mathrm{~s}$, neutralised by a $10 \%$ solution of acetic acid $\left(\mathrm{CH}_{3} \mathrm{COOH}\right)$, rinsed in water and then stored in glycerol. Dissected male genitalia were examined with a Nikon SMZ645 binocular microscope and then photographed using an eTREK DCM900 camera on MBI-1 microscope; images were processed with CombineZP software. Type material is deposited in the Zoological Museum of the Moscow State University (ZMMU).

\section{Species description}

Austrolimnophila (Austrolimnophila) vikhrevi sp.n. Figs $1-5$.

MATERIAL EXAMINED. Holotype $\sigma^{7}$, RUSSIA: Krasnodar Territory, Sochi/Khosta env., $43.54897^{\circ} \mathrm{N}, 39.8204^{\circ} \mathrm{E}, 18 . \mathrm{V} .2011$, D. Gavryushin leg. (dry-mounted, glued to a card point; in good condition, right hind leg missing, antennae intact). Paratypes: 3 $\sigma^{\top} \sigma^{\top}$, RUSSIA: Krasnodar Territory, Sochi/Khosta env., $43.5309^{\circ} \mathrm{N}$, $39.88232^{\circ}$ E, 14.V.2011, D. Gavryushin leg. (all dry-mounted, glued 
to card points; in good or very good condition, some legs missing, antennae intact).

DIAGNOSIS. Medium-sized fly with typical Austrolimnophila (s.str.) appearance. Body length ca. 8$8.5 \mathrm{~mm}$, wing length ca. 8.5-9 $\mathrm{mm}$.

DESCRIPTION. Male. Head grey, rostrum and palpi brownish yellow. Antennae nearly reaching bases of wings, brown except for the yellowish base of flagellomere 1, antennal flagellomeres elongate oval, twice as long as broad, gradually narrowed toward the apices of antennae, with usual sparse short hairs and long verticils; the longest of verticils roughly the length of corresponding segments.

Thorax mostly brownish yellow; cervical sclerites and pronotum brownish yellow; prescutum light brown, at certain angles appearing grey because of extensive yellowish grey pruinosity, with indistinct wide brown median area divided in two stripes; scutal lobes brown, their posterolateral corners and median area between the lobes greyish yellow; scutellum greyish yellow; mediotergite brownish yellow; pleurae brownish yellow, with yellowish grey pruinosity. Halteres with stems yellow, knobs somewhat darkened. Legs rather long, dirty yellow with tips of femora, tibiae and tarsi indistinctly darker, coxa and trochanters light yellow.

Wings with membrane weakly tinged with brown, veins brown, stigma indistinct yet present. Venation: $S c_{2}$, slightly beyond tip of $S c_{1}, r q$ on $R$ at approx. 0.45 its length, origin of $R s$ not less than half its length beyond the tip of $A_{2}, R s$ twice longer than $R_{3+4}$, its base angulated (sometimes with a short spur), crossvein $m$ $c u$ at the middle of discal cell which is small, its posterior/lower margin $\left(M_{3+4}\right)$ half the length of $M_{4}$ (in paratypes approx. 0.4 to 0.6 length of $M_{4}$ ); the distal section of $M_{1+2}$ ca. 0.25 length of $M_{1}$. The last character seems to be variable, in the paratypes the distal section of $M_{1+2}$ being ca. 0.3 to 0.6 length of $M_{1}$. Additionally, one of the paratypes has extra cross-veins in distal portions of cells $m$ in both wings.

Abdomen brownish yellow, tergites and sternites widely darkened laterally. Hypopygium (Figs 1-2) of moderate size, dark brown with reddish brown gonostyli. Tergite 9 posteriorly with moderately deep semicircular emargination with protruding postero-lateral corners; triangular lobe on each side of emargination. Gonocoxites cylindrical, slightly narrowed apically. Both gonostyli setose. Outer gonostyli slender, parallel-sided, gradually tapered distally into slightly curved, blackened terminal spine. Inner gonostyli very slender, moderately sinuous, obtuse at apex. Aedeagal complex (Figs 3-5) with parameres darkly pigmented, its posterior arms triangular, gently curved inwards, tips obtuse and widely separated (approx. at the width of aedeagus at its base). Aedeagus long but not extending beyond distal ends of gonocoxites, rather broad, gently curved in lateral aspect, gradually tapering to subacute tip. Dorsal apodeme of vesica of moderate length, strongly arched ventrally.

Female unknown.
ETYMOLOGY. This species is named after Nikita E. Vikhrev (Moscow, Russia), my friend and one of the world's leading experts in Muscoidea.

DISCUSSION. By the key to Western Palaearctic species provided by Starý [2014: 359-360] Austrolimnophila (Austrolimnophila) vikhrevi sp.n. runs out either at Austrolimnophila (Austrolimnophila) brevicellula Stary, 1977 or Austrolimnophila (Austrolimnophila) cretica Stary, 2014, differing from both of these two species in details of venation and structure of male terminalia indicated above.

DISTRIBUTION. Russia (Krasnodar Territory).

\section{Scleroprocta staryi sp.n.}

Figs 6-13.

MATERIAL EXAMINED. Holotype $\sigma^{r}$, RUSSIA: Krasnodar Territory, Lagonaki, $44.009^{\circ} \mathrm{N}, 39.994^{\circ} \mathrm{E}, 1700 \mathrm{~m}, 11 . \mathrm{V} .2012$, N. Vikhrev leg. (dry-mounted, glued to an insect pin; in good condition, both fore legs missing, antennae intact). Paratype: $\sigma^{7}$, same data (dry-mounted, glued to an insect pin; in good condition, legs and antennae intact).

DIAGNOSIS. Medium-sized dark greyish brown species with typical Scleroprocta appearance. Body length ca. 5-6 mm, wing length ca. 7-7.5 mm.

DESCRIPTION. Male. Head dark greyish brown, rostrum and palpi brown. Antennae long, reaching about half the length of abdomen, yellowish brown, antennal flagellomeres elongate oval, approx. 4 times as long as broad, with long yellowish suberect pubescense on all flagellomers; verticils roughly 0.8 length of corresponding segments.

Thorax almost uniformly dark greyish brown except for dorsopleural membranes which are somewhat yellowed. Halteres brownish yellow. Legs with coxa, trochanters and femora yellow, the latter widely darkened distally, especially fore femora, tibiae and tarsi brown.

Wings rather broad, wing membrane tinged with greyish brown, veins brown, stigma almost indistinct. Venation usual for the genus; $S c_{1}$ ending almost at the level of $r q, S c$ at the midlength of $R s, r q$ on $R_{2}$ (holotype) or at the point of furcation of $R_{2+3}$ (paratype); discal cell only slightly beyond $m-c u$, small, $M_{3+4}$ ca. 0.6 length of $M_{4}$.

Abdomen dark greyish brown, concolorous with thorax. Hypopygium (Figs 6-8) of moderate size, brown with darkened outer gonostyli and median portion of tergite 9. Median portion of tergite 9 (Fig. 13) large, rectangular, provided with stout spine-like sclerotised projection on each side of its anterior margin which extends far beyond its posterior margin; these spines are curved inwards in lateral aspect, gradually tapering into acute tips, and convergent (crossing each other in the image is due to deformation while dissecting). Gonocoxites and both gonostyli as in Figs 6-8, 13, of typical structure. Parameral plate reduced to transverse band above proximal part of aedeagus, subquadrate in shape, with moderately deep triangular emargination on posterior margin and obtuse postero-lateral corners. Aedeagus (Figs 9-11) of moderate size, stongly bent in the middle and bipartite distally in lateral aspect, the 


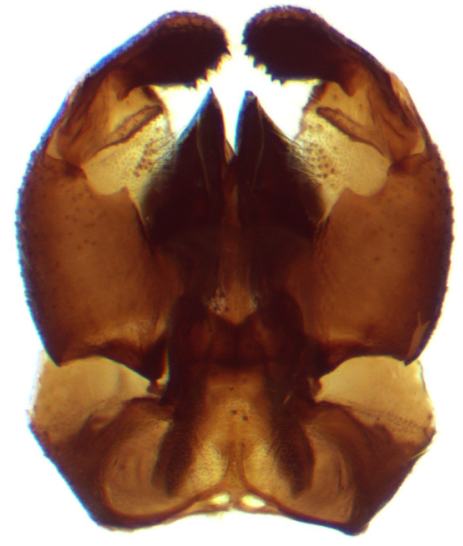

6

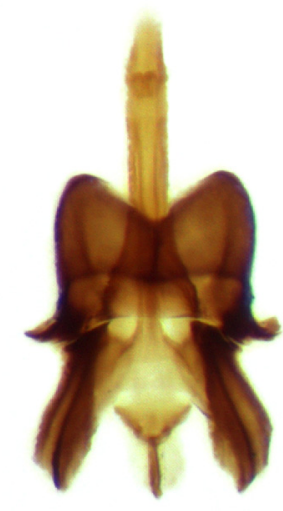

9

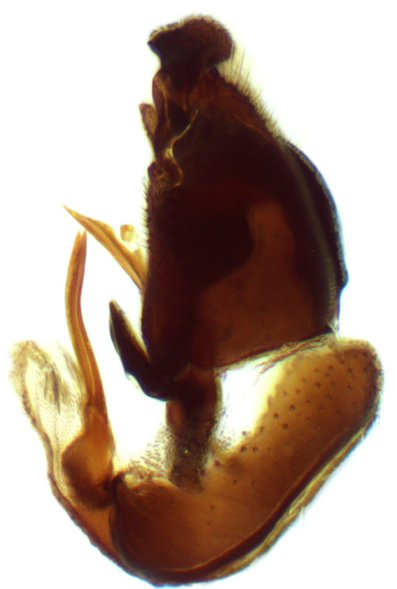

7

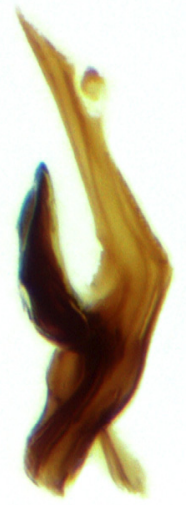

10

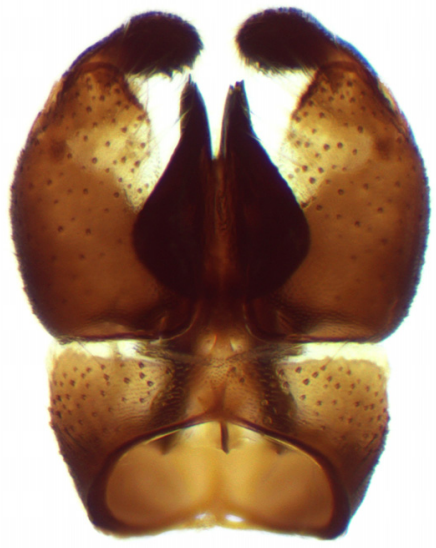

8

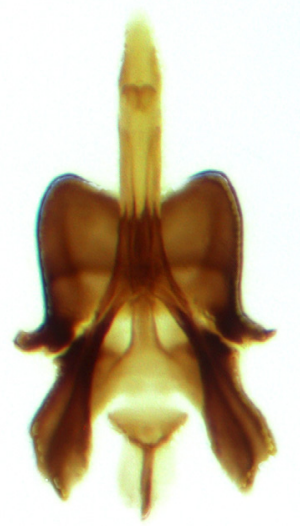

11

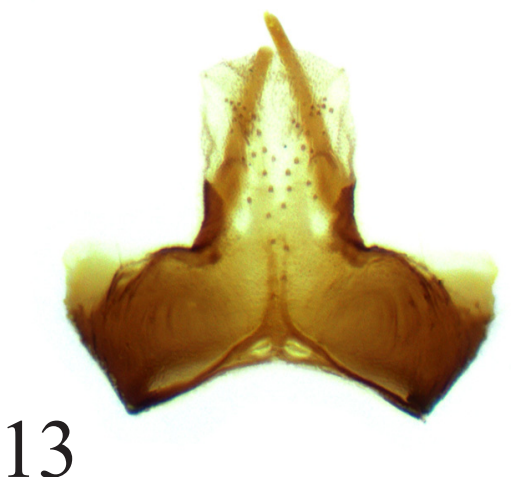

Figs 6-13. Scleroprocta staryi sp.n., holotype $0^{7}: 6-$ male hypopygium, dorsal view; 7 - same, lateral view; 8 - same, ventral view; 9 - aedeagal complex, dorsal view; 10 - same, lateral view; 11 - same, ventral view; 12 - gonopods, caudal view; 13 - tergite 9. Not on same scale.

Рис. 6-13. Scleroprocta staryi sp.n., голотип о?: 6 - гипопигий самца, вид сверху; 7 - то же, вид сбоку; 8 - то же, вид снизу; 9 - эдеагус, вид сверху; 10 - то же, вид сбоку; 11 - то же, вид снизу; 12 - гоноподиты, вид сверху; 13 - 9-й тергит. Масштаб разный.

upper part more slender, tapering into acute tip, the lower one bipartite in ventral aspect. Ventral plate (Figs 8, 12) extremely well developed, heavily sclero- tized, its posterior margin strongly protruding and narrowly bilobed; these lobes abruptly dilate anteriorly to form wide divergent protrusions over ventomesal por- 
tions of gonocoxites. Due to unusual development of the ventral plate, gonocoxites appear completely fused together in caudal view (Fig. 12). Dorsal apodeme of vesica rather small, with darkly pigmented triangular base and narrow median projection.

Female unknown.

ETYMOLOGY. This species is named in honour of Jaroslav Starý (Opava, Czech Republic), a prominent expert in Palaearctic Tipuloidea who contributed a lot to the knowledge of this genus.

DISCUSSION. By the key to Western Palaearctic species provided by Starý [2014: 359-360] Austrolimnophila (Austrolimnophila) vikhrevi sp.n. runs out either at Austrolimnophila (Austrolimnophila) brevicellula Stary, 1977 or Austrolimnophila (Austrolimnophila) cretica Stary, 2014, differing from both of these two species in details of venation and structure of male terminalia indicated above.

DISTRIBUTION. Russia (Krasnodar Territory).

\section{New records}

Subfamily Chioneinae

1. Ormosia (Ormosia) bicornis (de Meijere, 1920)

MATERIAL EXAMINED. $13 \sigma^{7} \sigma^{7}, 1$, RUSSIA: Krasnodar Territory, Sochi/Adler env., $43.4766^{\circ}$ N, 39.9067 E, 22.X.2009, 14, 15 and 18.X.2010, D. Gavryushin leg.

DISTRIBUTION. Widely distributed in Europe from Great Britain to Macedonia to Crimea. New record for mainland Russia. Appears to be locally common in late October.

2. Ormosia (Ormosia) longispina Savchenko, 1983

MATERIAL EXAMINED. $10^{7}$, RUSSIA: Krasnodar Territory, Varenikovskaya env., $45.083^{\circ} \mathrm{N}, 37.586^{\circ} \mathrm{E}, 27 . \mathrm{IV} .2014, \mathrm{~N}$ Vikhrev leg.

DISTRIBUTION. Previously known only from Armenia. New record for Russia.

Subfamily Limnophilinae

\section{Eloeophila minor Stary, 2009}

MATERIAL EXAMINED. $10^{7}, 2$ O 9 , RUSSIA: Krasnodar Territory, Lagonaki, $44.009^{\circ} \mathrm{N}, 39.994^{\circ} \mathrm{E}, 1700 \mathrm{~m}, 11 . \mathrm{V} .2012$, N. Vikhrev leg.

DISTRIBUTION. Previously known only from the Czech Republic and Slovakia. New record for Russia.

\section{Prionolabis subcognata Savchenko, 1971}

MATERIAL EXAMINED. $10^{7}$, RUSSIA: Krasnodar Territory, Sochi distr., Krasnaya Polyana env., 2200 m, 25.VI.2011, N. Vikhrev leg.; $7 \bigcirc^{7} \bigcirc^{7}$, RUSSIA: Krasnodar Territory, Lagonaki, $44.009^{\circ} \mathrm{N}, 39.994^{\circ} \mathrm{E}, 1700 \mathrm{~m}, 27-30 . \mathrm{VI} .2011$, N. Vikhrev leg.; 5 $\sigma^{7} \sigma^{7}$, RUSSIA: Krasnodar Territory, Lagonaki, $44.012^{\circ} \mathrm{N}, 39.034^{\circ} \mathrm{E}$, 1500m, 27-30.VI.2011, N. Vikhrev leg.

DISTRIBUTION. Previously known only from Georgia. New record for Russia. Probably first record since original description. Appears to be locally common at moderate altitudes in late June.

\section{Subfamily Limoniinae}

\section{Elliptera omissa Schiner, 1863}

MATERIAL EXAMINED. $10^{\top}, 1$, RUSSIA: Krasnodar Territory, Sochi distr., Khosta env., $43.55^{\circ} \mathrm{N}, 39.89^{\circ} \mathrm{E}, 24 . \mathrm{VI} .2011$, N. Vikhrev leg.

DISTRIBUTION. Widely distributed in Europe from Belgium to Italy to Ukraine. New record for Russia.

ACKNOWLEDGEMENTS. I would like to extend my sincere gratitude to Dr. Jaroslav Starý (Olomouc-Nedvìzí \& Silesian Museum, Opava, Czech Republic) for valuable comments on the new species and Dr. Nikita E. Vikhrev (Zoological Museum of Moscow University, Moscow, Russia) for encouragement and support all these years.

ERRATUM. In my previous article [Gavryushin D.I. 2014. New species of Gonomyia Meigen, 1818 (Diptera: Limoniidae) from Middle Asia // Russian Entomol. J. Vol.23. No.1. P.71-74], the incorrect longitude is given in description of material of Gonomyia kiritschenkoi, it should read $68.38^{\circ} \mathrm{E}$.

\section{References}

Alexander C.P., Byers G.W. 1981. Tipulidae // McAlpine J.F., Peterson B.V., Shewell G.E, Teskey H.J., Vockeroth J.R., Wood D.M. (coordinators). Manual of Nearctic Diptera. Vol.1. Ottawa: Research Branch. Agriculture Canada. Monograph 27. P.153-190.

Gavryushin D.I. 2011. A new species of Erioptera Meigen, 1803 (Diptera, Limoniidae) from Krasnodar Territory // Russian Entomological Journal. Vol.20. No.1. P.109-112.

Lantsov V.I. 2009. New records for Limoniidae and Pediciidae (Diptera) from the Caucasus, Russia // Lantsov V. (ed.). Crane flies. History, taxonomy and ecology (Diptera: Tipulidae, Limoniidae, Pediciidae, Trichoceridae, Ptychopteridae, Tanyderidae). Memorial volume dedicated to Dr. Charles Paul Alexander (1889-1981), Dr. Bernhard Mannheims (1909-1971) and Dr. Evgeniy Nikolaevich Savchenko (1909-1994). Zoosymposia. No.3. P.111-114.

McAlpine J.F. 1981. Morphology and terminology-adults // McAlpine J.F., Peterson B.V., Shewell G.E, Teskey H.J., Vockeroth J.R., Wood D.M. (coordinators). Manual of Nearctic Diptera. Vol.1. Ottawa: Research Branch. Agriculture Canada. Monograph 27. P.9-63.

Oosterbroek P. 2015. Catalogue of the Craneflies of the World ((Diptera, Tipuloidea: Pediciidae, Limoniidae, Cylindrotomidae, Tipulidae), online at: http://nlbif.eti.uva.nl/ccw/ (last accessed June 09, 2015).

Starý J. 1977. Zwei neue Austrolimnophila-Arten aus dem Mittelmeerraum (Diptera, Limoniidae) // Entomologica (Bari). No.13. P.63-70.

Starý J. 2008. Three new European species of the genus Scleroprocta Edwards, 1938 (Diptera, Limoniidae) // Biologia (Bratislava). Vol.63. No.1. P.120-126.

Starý J. 2014. Two new species of Austrolimnophila from the Mediterranean (Diptera: Limoniidae) // Acta Entomologica Musei Nationalis Pragae. Vol.54. No.1. P.355-360. 